\title{
Vigor tests to evaluate the physiological quality of corn seeds cv. 'Sertanejo'
}

\author{
Daniela Vieira dos Anjos Sena ${ }^{{ }^{*}}$ Edna Ursulino Alves ${ }^{2}$ Dayana Silva de Medeiros ${ }^{1}$
}

\begin{abstract}
'Programa de Pós-graduação em Agronomia (PPGA), Centro de Ciências Agrárias, Universidade Federal da Paraíba (UFPB), Campus II, Rod. 079, km 12, 58397-000, Areia, PB, Brasil. E-mail: danielavieirasena@yahoo.com.br. "Corresponding author.

${ }^{2}$ Departamento de Fitotecnia e Ciências Ambientais, Universidade Federal da Paraíba (UFPB), Areia, PB, Brasil.
\end{abstract}

\begin{abstract}
The vigor tests are intended to monitor the quality of seeds as it allows reliably distinguish lots of low and high vigor, providing additional information to the germination test. So in this study the objective was to identify the most efficient vigor tests on stratification of lots of corn seeds cv. 'Sertanejo'. The experiment was conducted at Laboratory of Seed Analysis at the Center of agricultural Science of the Universidade Federal da Paraiba, using samples from 20 seed lots in a completely randomized design. For characterization of the lots it was evaluated water content, germination and vigor (cold test, electrical conductivity, accelerated aging, seedling emergence in field and germination at low temperatures). The accelerated aging, electrical conductivity and field emergence of seedlings tests are the most efficient for classification of lots of corn seeds $\mathrm{cv}$. 'Sertanejo' in levels of vigor, been the seeds of lot 1 the most vigorous.
\end{abstract}

Key words: Zea mays L., viability, seed analysis.

Testes de vigor para avaliar a qualidade fisiológica de sementes de milho cv. 'Sertanejo'

RESUMO: Os testes de vigor têm como finalidade monitorar a qualidade das sementes, pois permite distinguir com segurança os lotes de baixo e alto vigor, fornecendo informações adicionais ao teste de germinação. Assim, no presente trabalho, objetivou-se identificar os testes de vigor mais eficientes na estratificação de lotes de sementes de milho cv. 'Sertanejo'. O experimento foi realizado no Laboratório de Análise de Sementes do Centro de Ciências Agrárias da Universidade Federal da Paraiba, utilizando amostras de 20 lotes de sementes, em delineamento inteiramente ao acaso. Para caracterização dos lotes foram avaliados o teor de água, a germinação e o vigor (teste de frio, condutividade elétrica, envelhecimento acelerado, emergência de plântulas em campo e germinação a baixa temperatura). Os testes de envelhecimento acelerado, condutividade elétrica e emergência de plântulas em campo são os mais eficientes para classificação dos lotes de sementes de milho cv. 'Sertanejo', em niveis de vigor, sendo as sementes do lote 1 mais vigorosas.

Palavras-chave: Zea mays $L$., viabilidade, análises de sementes.

\section{INTRODUCTION}

Corn (Zea mays L.) is an important crop in the world economy whose is characterized by many forms of use, from feeding to the high-tech industry (PICARELLI, 2012). In this context, Brazil has emerged as the third largest producer, behind only the US and China (EMBRAPA MILHO \& SORGO, 2012). The use of corn as feed represents the largest share of consumption, about $70 \%$ worldwide, and in the United States it represents about $50 \%$, while in Brazil ranges from 70 to $80 \%$ used for this purpose; despite low participation in food, generally derivatives from corn has great importance because meet the food demands, especially in regions with low income (PICARELLI, 2012).
The use of high quality seeds is the basis for increasing yield, and the physiological component of seed quality has been subject of numerous studies, since the seeds are subjected to a series of degenerative changes after maturity (FREITAS \& NASCIMENTO, 2006). Also the use of vigor testing is useful in monitoring the quality of seeds which from the maturity occurs reduction in vigor that precedes the loss of viability (DIAS \& MARCOS FILHO, 1995). Vigor tests detect significant differences in physiological quality of seeds with similar germination, providing additional information to those obtained by the germination test, which are classified as direct methods, because they try to simulate the conditions that occur in the field, and indirectly aim to evaluate attributes that are indirectly 
related to vigor (physical, biological and physiological) of the seeds (CARVALHO \& NAKAGAWA, 2012).

Results of vigor tests to distinguish safely lots of high from those with low vigor, detected differences that are related to the behavior of seed during storage and after sowing (MARCOS FILHO, 2005). The high seed vigor is a key factor in order to have a uniform germination, ensuring optimum plant stand; therefore, it becomes increasingly necessary to make the improvement of vigor tests (OLIVEIRA et al., 2009). Accordingly, it is recommended the use of more than one vigor test to increase information and reduce errors associated with the decision to accept or reject a lot of seeds for storage or planting (MENDONÇA et al., 2008).

The efficiency of the separating seed lots of the electrical conductivity test can be found in seeds of Vigna unguiculata (BATISTA et al., 2012) and Vigna radiata L. (ARAÚJO et al., 2011). For seeds of Triticum aestivum (OHLSON et al., 2010) and Sorghum bicolor (L.) Moench (SOARES et al., 2010) the accelerated aging test was effective regarding the effect of differentiation levels. Given the above, this study aimed to identify the most efficient vigor tests on stratification of lots of corn seeds cv. 'Sertanejo'.

\section{MATERIALS AND METHODS}

The research was conducted at the Laboratory of seed analysis in the center of agricultural science from the Universidade Federal da Paraiba, Campus II, in Areia - PB, with 20 lots of corn seeds cultivar Sertanejo obtained in unit of seed processing (UBS) of the state agricultural research company of Paraíba (EMEPA - PB), that after obtaining the seeds they were subjected to germination and vigor tests.

Moisture content - for this determination, it was used the standard oven method at $105 \pm 3^{\circ} \mathrm{C}$ for 24 hours and the percentage of water content was based on its moist weight according to BRAZIL (2009), with modification in the number of seeds and repetitions, which were four replicates of 25 seeds of each lot.

Germination test - conducted on four samples of 50 seeds for each lot, distributed in paper rolls "germitest" moistened with distilled water in the amount equivalent to 3.0 times the mass of the dry substrate. The seeds were germinated in a germination chamber at $30^{\circ} \mathrm{C}$ with a photoperiod of $8 / 16$ hours of light and dark, respectively. Counts were performed at four and seven days after the test installation according to the Rules for Seed Analysis (BRAZIL, 2009).

Cold test - for the installation of the test it was adopted the same procedures described in germination test, but the four rolls containing seeds were kept in a capped containers in a refrigerator at a constant temperature of $10^{\circ} \mathrm{C}$ for a period of seven days, and then the plastic boxes were removed, uncapped and the rolls were placed in a germination chamber at $25^{\circ} \mathrm{C}$, remaining in this condition for four days (BARROS et al., 1999), by noting, at the end of this period, the number of normal seedlings.

Eletrical conductivity - it was used four samples of 50 seeds from each lot appropriately weighed which were put to soak in $75 \mathrm{~mL}$ of deionized water for a period of 24 hours in a germination chamber at $25^{\circ} \mathrm{C}$. After imbibition made to read the electrical conductivity of the soaking solution conductivity, whose results were divided by sample weight and the final results expressed in $\mu \mathrm{Scm}^{-1} \mathrm{~g}^{-1}$ (VIEIRA \& KRZYZANOWSKI, 1999).

Accelerated aging - for the instalation of this test it was used box of the gerbox type, mesuaring $(11 \times 11 \times 3,5 \mathrm{~cm})$ containing $40 \mathrm{ml}$ of distilled water, with a metallic screen adapted on its interior, which distributed a uniform layer of seeds, being capped and then placed in chamber at $42^{\circ} \mathrm{C}$ for 96 hours (MARCOS FILHO, 1999). After this period the germination test was installed using four replications of 50 seeds (BRAZIL, 2009), and on the seventh day there was the count of the number of normal seedlings.

Field seedling emergence - the test was conducted on four samples of 50 seeds for each lot, and the sowing $1.5 \mathrm{~cm}$ deep in ridges with length $1.0 \mathrm{~m}$, $20 \mathrm{~cm}$ apart from each other, with daily moistening. The count was performed on the tenth day after sowing and the results expressed as a percentage.

Germination in low temperature - it was used four samples of 50 seeds for each lot, germinated in papper rolls "germitest" moistened with distilled water equivalent to 2.5 times the mass of dry substrate, at $18^{\circ} \mathrm{C}$ (DIAS \& ALVARENGA, 1999) being performed a single assessment at seven days after planting. The results were expressed as mean percentage of normal seedlings (BRASIL, 2009) to interpret the results it was used measurement of normal seedlings.

The experimental design was completely randomized and four replications, and the data were submitted to analysis of variance and the means compared by Scott-Knott test at $5 \%$ of probability.

\section{RESULTS AND DICUSSION}

The water content of seeds ranged from 11.3 to $12.5 \%$ (Table 1 ), according to COIMBRA et 
Table 1 - Means of water content, germination test, cold test and electrical conductivity of representative samples of lots of corn seeds cv. 'Sertanejo'.

\begin{tabular}{|c|c|c|c|c|c|}
\hline \multirow[t]{2}{*}{ Lots } & Water content & Germination test & Cold test & $\begin{array}{l}\text { Water content before } \\
\text { eletrical conductivity }\end{array}$ & \multirow[t]{2}{*}{$\begin{array}{l}\text { Electrical conductivity } \\
\left(\mu \mathrm{S} \mathrm{cm}^{-1} \mathrm{~g}^{-1}\right)\end{array}$} \\
\hline & -----------------. & ------------------. & \%o-------- & ------------------------------ & \\
\hline 1 & $11.3 \mathrm{~b}$ & 97 a & $81 \mathrm{~b}$ & $11.8 \mathrm{~b}$ & $15.18 \mathrm{a}$ \\
\hline 2 & $12.4 \mathrm{a}$ & 94 a & $94 \mathrm{a}$ & $12.4 \mathrm{a}$ & $20.07 \mathrm{~b}$ \\
\hline 3 & $11.7 \mathrm{a}$ & $92 \mathrm{~b}$ & $90 \mathrm{a}$ & $11.3 \mathrm{~b}$ & $22.62 \mathrm{c}$ \\
\hline 4 & $11.8 \mathrm{a}$ & $90 \mathrm{~b}$ & $68 \mathrm{~d}$ & $11.7 \mathrm{~b}$ & $21.56 \mathrm{c}$ \\
\hline 5 & $11.7 \mathrm{a}$ & $90 \mathrm{~b}$ & $88 \mathrm{a}$ & $11.8 \mathrm{~b}$ & $27.15 \mathrm{~d}$ \\
\hline 6 & $11.4 \mathrm{~b}$ & $89 \mathrm{~b}$ & $87 \mathrm{a}$ & $11.6 \mathrm{~b}$ & $20.76 \mathrm{~b}$ \\
\hline 7 & $11.9 \mathrm{a}$ & $86 \mathrm{c}$ & $40 \mathrm{f}$ & $11.9 \mathrm{a}$ & $23.27 \mathrm{c}$ \\
\hline 8 & $11.4 \mathrm{~b}$ & $86 \mathrm{c}$ & $80 \mathrm{~b}$ & $11.4 \mathrm{~b}$ & $28.47 \mathrm{~d}$ \\
\hline 9 & $11.9 \mathrm{a}$ & $85 \mathrm{c}$ & $64 \mathrm{~d}$ & $12.1 \mathrm{a}$ & $24.98 \mathrm{c}$ \\
\hline 10 & $11.3 \mathrm{~b}$ & $84 \mathrm{c}$ & $75 \mathrm{c}$ & $11.3 \mathrm{~b}$ & $19.70 \mathrm{~b}$ \\
\hline 11 & $12.0 \mathrm{a}$ & $81 \mathrm{~d}$ & $67 \mathrm{~d}$ & $11.6 \mathrm{~b}$ & $29.76 \mathrm{~d}$ \\
\hline 12 & $12.5 \mathrm{a}$ & $79 \mathrm{~d}$ & $65 \mathrm{~d}$ & $12.5 \mathrm{a}$ & $31.88 \mathrm{~d}$ \\
\hline 13 & $11.9 \mathrm{a}$ & $77 \mathrm{~d}$ & $70 \mathrm{c}$ & $12.0 \mathrm{a}$ & $24.96 \mathrm{c}$ \\
\hline 14 & $11.8 \mathrm{a}$ & $70 \mathrm{e}$ & $55 \mathrm{e}$ & $11.8 \mathrm{~b}$ & $24.63 \mathrm{c}$ \\
\hline 15 & $12.2 \mathrm{a}$ & $67 \mathrm{e}$ & $34 \mathrm{f}$ & $12.2 \mathrm{a}$ & $54.83 \mathrm{f}$ \\
\hline 16 & $12.1 \mathrm{a}$ & $61 \mathrm{f}$ & $20 \mathrm{~g}$ & $11.9 \mathrm{a}$ & $31.63 \mathrm{~d}$ \\
\hline 17 & $12.3 \mathrm{a}$ & $61 \mathrm{f}$ & $53 \mathrm{e}$ & $12.3 \mathrm{a}$ & $22.24 \mathrm{c}$ \\
\hline 18 & $12.2 \mathrm{a}$ & $55 \mathrm{~g}$ & $56 \mathrm{e}$ & $12.8 \mathrm{a}$ & $40.80 \mathrm{e}$ \\
\hline 19 & $11.9 \mathrm{a}$ & $57 \mathrm{~g}$ & $59 \mathrm{e}$ & $11.9 \mathrm{a}$ & $38.99 \mathrm{e}$ \\
\hline 20 & $12.2 \mathrm{a}$ & $43 \mathrm{~h}$ & $54 \mathrm{e}$ & $12.2 \mathrm{a}$ & $30.76 \mathrm{~d}$ \\
\hline
\end{tabular}

Means followed by the same letter in the column do not differ statistically from each other, $5 \%$ probability by Scott-Knott test.

al. (2009) the similarity values is essential so the tests are not affected by differences in metabolic activity of the seeds, wetting speed and deterioration.

According to the results of the germination test (Table 1), there are significant differences between samples of seeds from the 20 lots, and for the samples from lot 1 and 2 it was found higher germination, while in the representative sample from the lot 20 it was found the lowest germination performance. Based on the cold test results, representative samples of the lots 2, 3, 5 and 6 were classified as higher physiological quality, averaging $87-94 \%$ germination, samples of lots 1 and 8 with average quality (80-81\%) and the remaining samples were classified as low vigor, averaging less than $75 \%$ (Table 1). According to the International Seed Testing Association - ISTA (1981) and the Association of Official Seed Analysts - AOSA (1983) cold test is considered as the most important for the vigor of corn seed. According GRABE (1976) lots of suitable quality should be at least $70-80 \%$ of normal seedlings in the cold without soil test.

By analyzing the physiological quality of sweet corn seeds from plants grown under different nitrogen rates, ZUCARELI et al. (2012) reported significant differences between nitrogen application time by the cold test. GUISCEM et al. (2010) reported that the cold test is an alternative as consistent as the accelerated aging test on evaluating feijão macassar seeds. The cold test was efficient to evaluate the physiological quality of rice seeds subjected to different drying temperatures (MENEZES et al., 2012).

Also in the table 1 it was observed that the water content before the electrical conductivity varied between 11.3 and $12.5 \%$ within the standards suggested by AOSA (1983) that recommend the moisture content of the lots to be varying between 10 and $17 \%$ prior to the evaluation of the electrical conductivity. VIEIRA et al. (2002) reported that in general it has been reported that very low levels of water $(\leq 10 \%)$ or very high $(\geq 17 \%)$ influenced significantly the results.

Seeds from lot 1 with lower electrical conductivity were the best in physiological quality; however,' with a discordant result from the cold test, which indicated lot 1 as medium vigor (Table 1). Lots 2, 6 and 10 were classified as intermediate vigor and the others as low vigor. 
Similar results to those were obtained by RIBEIRO et al. (2009) and COIMBRA et al. (2009) using the test in the evaluation of lots of popcorn seeds and sweet corn, respectively.

According to the data of table 2 it was found that the water content of the seeds before the accelerated aging was similar between samples of the lots ranging from 10.1 to $11.2 \%$, but after accelerated aging the water content varied from 16.2 to $24.2 \%$, with a range of $8 \%$ between the lowest and highest value.

The accelerated aging test indicated only the sample from the lot 1 as more vigorous, a similar result to the electrical conductivity test; while the samples of the lots 3 to 6 were classified as medium effect and the samples from the lot 20 as the worse performance (Table 2).

This test was efficient in evaluating seeds of Oryza sativa L. (TUNES et al., 2012), Zea mays L. (VENANCIO et al., 2012) and Sorghum bicolor (SOARES et al., 2010). According to BITTENCOURT et al. (2012) the accelerated aging test associated with the tetrazolium test in seeds, provided similar information aas the one provided by the germination test.

The field seedling emergence test allowed differ lots of high vigor (1 and 3), medium vigor, with emergency between $83-77 \%$ and lots of low vigor with emergency less than $76 \%$. Similar results were obtained in lots of bean seeds (LUDWIG et al., 2008) and wheat (OHLSON et al., 2010), in which the seedling emergency field test was efficient in classifying them into vigor levels.

Results of germination test at low temperature (Table 3) showed that the samples from the lots 1, 2, 3, 5, 6 and 7 were the most vigorous, with a percentage of germination between $94-98 \%$. Samples from the lots 4 and 11 were considered as a medium vigor with germination over $85 \%$ while the seed germination of lots with low vigor was between 84 and 29\%. The highest percentage germination of seeds when exposed to conditions of low temperatures, probably due to tolerance of seeds of the cultivar Sertanejo to these conditions.

In the assessment of seedling length at low temperature samples of the lots 1 and 6 were classified as the best physiological performance in both the variables used; In regard to the dry mass the lot 6 stood out as high-vigor and the seeds from lot 1 as a medium vigor, and samples of the lots 15 and 20 were classified as worst performers.

According to the data in the table 4 it was observed that the electrical conductivity test got negative correlation; however, significant with the

Table 2 - Means of water content, germination percentage in accelerated aging and field emergence of representative samples of lots of corn seeds cv. 'Sertanejo'.

\begin{tabular}{|c|c|c|c|c|}
\hline \multirow{2}{*}{ Lots } & \multicolumn{2}{|c|}{ Water content $(\%)$} & \multirow{2}{*}{$\begin{array}{c}\text { Germination in the accelerated } \\
\text { aging }(\%)\end{array}$} & \multirow{2}{*}{ Field emergence } \\
\hline & Before the accelerated aging & After the accelerated aging & & \\
\hline 1 & $10.1 \mathrm{~b}$ & $20.4 \mathrm{e}$ & $91 \mathrm{a}$ & $93 \mathrm{a}$ \\
\hline 2 & $11.0 \mathrm{a}$ & $22.1 \mathrm{c}$ & $60 \mathrm{~d}$ & $69 \mathrm{c}$ \\
\hline 3 & $11.1 \mathrm{a}$ & $21.0 \mathrm{~d}$ & $83 \mathrm{~b}$ & $87 \mathrm{a}$ \\
\hline 4 & $10.8 \mathrm{a}$ & $24.1 \mathrm{a}$ & $69 \mathrm{c}$ & $81 \mathrm{~b}$ \\
\hline 5 & $11.1 \mathrm{a}$ & $21.9 \mathrm{c}$ & $59 \mathrm{~d}$ & $77 \mathrm{~b}$ \\
\hline 6 & $10.2 \mathrm{~b}$ & $21.3 \mathrm{c}$ & $83 \mathrm{~b}$ & $81 \mathrm{~b}$ \\
\hline 7 & $10.6 \mathrm{~b}$ & $22.6 \mathrm{~b}$ & $69 \mathrm{c}$ & $80 \mathrm{~b}$ \\
\hline 8 & $10.7 \mathrm{a}$ & $23.6 \mathrm{a}$ & $61 \mathrm{~d}$ & $69 \mathrm{c}$ \\
\hline 9 & $11.1 \mathrm{a}$ & $23.8 \mathrm{a}$ & $69 \mathrm{c}$ & $78 \mathrm{~b}$ \\
\hline 10 & $10.3 \mathrm{~b}$ & $23.5 \mathrm{a}$ & $67 \mathrm{c}$ & $78 \mathrm{~b}$ \\
\hline 11 & $10.3 \mathrm{~b}$ & $20.3 \mathrm{e}$ & $64 d$ & $83 \mathrm{~b}$ \\
\hline 12 & $11.1 \mathrm{a}$ & $17.5 \mathrm{f}$ & $61 \mathrm{~d}$ & $55 \mathrm{~d}$ \\
\hline 13 & $11.2 \mathrm{a}$ & $16.2 \mathrm{~g}$ & $49 \mathrm{e}$ & $57 \mathrm{~d}$ \\
\hline 14 & $10.5 \mathrm{~b}$ & $21.9 \mathrm{c}$ & 49 e & $57 \mathrm{~d}$ \\
\hline 15 & $10.8 \mathrm{a}$ & $21.7 \mathrm{c}$ & $39 \mathrm{f}$ & $74 \mathrm{c}$ \\
\hline 16 & $10.9 \mathrm{a}$ & $22.9 \mathrm{~b}$ & 49 e & $69 c$ \\
\hline 17 & $10.6 \mathrm{~b}$ & $22.0 \mathrm{c}$ & $51 \mathrm{e}$ & $70 \mathrm{c}$ \\
\hline 18 & $11.1 \mathrm{a}$ & $22.0 \mathrm{c}$ & $56 \mathrm{e}$ & $46 \mathrm{e}$ \\
\hline 19 & $10.2 \mathrm{~b}$ & $22.1 \mathrm{c}$ & $41 \mathrm{f}$ & $80 \mathrm{~b}$ \\
\hline 20 & $11.0 \mathrm{a}$ & $23.1 \mathrm{~b}$ & $26 \mathrm{~g}$ & $35 \mathrm{f}$ \\
\hline
\end{tabular}

Means followed by the same letter in the column do not differ statistically from each other, $5 \%$ probability by Scott-Knott test. 
Table 3 - Means of vigor (at low temperature germination, length and seedling dry weight) of representative samples of lots of corn seeds cv. 'Sertanejo'.

\begin{tabular}{|c|c|c|c|c|c|}
\hline \multirow{2}{*}{ Lots } & \multirow{2}{*}{ Germination $(\%)$} & \multicolumn{2}{|c|}{-----------------Length (cm)----------------- } & \multicolumn{2}{|c|}{ 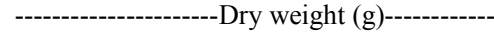 } \\
\hline & & Shoot & Root & Shoot & Root \\
\hline 1 & $96 \mathrm{a}$ & $2.52 \mathrm{a}$ & $7.28 \mathrm{a}$ & $0.0068 \mathrm{~b}$ & $0.0081 \mathrm{~b}$ \\
\hline 2 & $95 \mathrm{a}$ & $1.37 \mathrm{e}$ & $4.87 \mathrm{~d}$ & $0.0031 \mathrm{~h}$ & $0.0038 \mathrm{e}$ \\
\hline 3 & $98 \mathrm{a}$ & $1.88 \mathrm{c}$ & $5.86 \mathrm{~b}$ & $0.0055 \mathrm{c}$ & $0.0054 \mathrm{c}$ \\
\hline 4 & $91 \mathrm{~b}$ & $2.22 \mathrm{~b}$ & $5.12 \mathrm{c}$ & $0.0049 \mathrm{~d}$ & $0.0045 \mathrm{~d}$ \\
\hline 5 & $94 \mathrm{a}$ & $2.32 \mathrm{~b}$ & $5.85 \mathrm{~b}$ & $0.0054 \mathrm{c}$ & $0.0056 \mathrm{c}$ \\
\hline 6 & 95 a & $2.67 \mathrm{a}$ & $7.62 \mathrm{a}$ & $0.0075 \mathrm{a}$ & $0.0100 \mathrm{a}$ \\
\hline 7 & $97 \mathrm{a}$ & $1.50 \mathrm{~d}$ & $6.16 \mathrm{~b}$ & $0.0035 \mathrm{~g}$ & $0.0047 \mathrm{~d}$ \\
\hline 8 & $82 \mathrm{c}$ & $1.64 \mathrm{~d}$ & $5.52 \mathrm{c}$ & $0.0042 \mathrm{f}$ & $0.0050 \mathrm{~d}$ \\
\hline 9 & $84 \mathrm{c}$ & $1.79 \mathrm{c}$ & $4.67 \mathrm{~d}$ & $0.0042 \mathrm{f}$ & $0.0034 \mathrm{f}$ \\
\hline 10 & $81 \mathrm{c}$ & $1.60 \mathrm{~d}$ & $5.89 \mathrm{~b}$ & $0.0045 \mathrm{e}$ & $0.0054 \mathrm{c}$ \\
\hline 11 & $89 \mathrm{~b}$ & $2.35 \mathrm{~b}$ & $5.72 \mathrm{~b}$ & $0.0050 \mathrm{~d}$ & $0.0053 \mathrm{c}$ \\
\hline 12 & $77 \mathrm{~d}$ & $1.24 \mathrm{e}$ & $3.35 \mathrm{e}$ & $0.0035 \mathrm{~g}$ & $0.0034 \mathrm{f}$ \\
\hline 13 & $77 \mathrm{~d}$ & $1.17 \mathrm{f}$ & $4.89 \mathrm{~d}$ & $0.0036 \mathrm{~g}$ & $0.0038 \mathrm{e}$ \\
\hline 14 & $65 \mathrm{f}$ & $0.91 \mathrm{f}$ & $3.23 \mathrm{e}$ & $0.0024 \mathrm{i}$ & $0.0031 \mathrm{f}$ \\
\hline 15 & $29 \mathrm{i}$ & $1.08 \mathrm{f}$ & $2.95 \mathrm{e}$ & $0.0019 \mathrm{j}$ & $0.0018 \mathrm{~g}$ \\
\hline 16 & $71 \mathrm{e}$ & $1.44 \mathrm{~d}$ & $4.79 \mathrm{~d}$ & $0.0045 \mathrm{e}$ & $0.0048 \mathrm{~d}$ \\
\hline 17 & $59 \mathrm{~g}$ & $1.31 \mathrm{e}$ & $4.54 \mathrm{~d}$ & $0.0031 \mathrm{~h}$ & $0.0045 \mathrm{~d}$ \\
\hline 18 & $73 \mathrm{e}$ & $1.80 \mathrm{c}$ & $5.48 \mathrm{c}$ & $0.0047 \mathrm{e}$ & $0.0047 \mathrm{~d}$ \\
\hline 19 & $71 \mathrm{e}$ & $1.28 \mathrm{e}$ & $4.56 \mathrm{~d}$ & $0.0041 \mathrm{f}$ & $0.0036 \mathrm{e}$ \\
\hline 20 & $47 \mathrm{~h}$ & $0.85 \mathrm{f}$ & $2.74 \mathrm{e}$ & $0.0017 \mathrm{j}$ & $0.0020 \mathrm{~g}$ \\
\hline
\end{tabular}

Means followed by the same letter in the column do not differ statistically from each other, $5 \%$ probability by Scott-Knott test.

cold test $(\mathrm{r}=0.518)$ showing that increases in electrical conductivity values corresponded to reductions in germination percentage in the cold test. There was also a significant correlation between the data from the low temperature germination test and other tests used, with the highest values obtained in the cold test $(r=0.614)$, electrical conductivity $(\mathrm{r}=-0.671)$ and accelerated aging $(\mathrm{r}=0.781)$. Although the data in table 4 , reported that the accelerated aging test correlated negatively, results with the conductivity test $(\mathrm{r}=-0.578)$ were significant.

Table 4 - Correlation coefficients between the mean values of water content and test of vigor of corn seeds cv. 'Sertanejo'.

\begin{tabular}{|c|c|c|c|c|c|c|c|c|c|c|c|}
\hline & TA & $\mathrm{TF}$ & TAC & $\mathrm{CE}$ & GBT & CPABT & CRBT & MSRBT & MSPABT & EA & TAAEA \\
\hline $\mathrm{TF}$ & $-0.297^{* *}$ & - & & & & & & & & & \\
\hline TAC & $0.621^{* *}$ & $-0.236^{*}$ & - & & & & & & & & \\
\hline $\mathrm{CE}$ & $0.286^{* *}$ & $-0.518^{* *}$ & $0.179^{*}$ & - & & & & & & & \\
\hline GBT & $-0.311^{* *}$ & $0.614^{* *}$ & $-0.319^{* *}$ & $-0.671^{* *}$ & - & & & & & & \\
\hline CPABT & $-0.371^{* *}$ & $0.470^{* *}$ & $-0.368^{* *}$ & $-0.343^{* *}$ & $0.659^{* *}$ & - & & & & & \\
\hline CRBT & $-0.454^{* *}$ & $0.469^{* *}$ & $-0.417^{* *}$ & $-0.508^{* *}$ & $0.754^{* *}$ & $0.801^{* *}$ & - & & & & \\
\hline MSRBT & $-0.469^{* *}$ & $0.464^{* *}$ & $-0.368^{* *}$ & $-0.513^{* *}$ & $0.647^{* *}$ & $0.786^{* *}$ & $0.881^{* *}$ & - & & & \\
\hline MSPAB & $-0.466^{* *}$ & $0.488^{* *}$ & $-0.422^{* *}$ & $-0.419^{* *}$ & $0.709^{* *}$ & $0.863^{* *}$ & $0.856^{* *}$ & $0.904^{* *}$ & - & & \\
\hline EA & $-0.451^{* *}$ & $0.545^{* *}$ & $-0.388^{* *}$ & $-0.578^{* *}$ & $0.781^{* *}$ & $0.716^{* *}$ & $0.764^{* *}$ & $0.749^{* *}$ & $0.773^{* *}$ & - & \\
\hline TAAEA & $0.176^{\mathrm{ns}}$ & $-0.053^{\mathrm{ns}}$ & $0.210^{*}$ & $0.168^{\mathrm{ns}}$ & $-0.105^{\mathrm{ns}}$ & $-0.276^{* *}$ & $-0.317^{* *}$ & $-0.360^{* *}$ & $-0.262^{* *}$ & $-0.162^{\mathrm{ns}}$ & - \\
\hline TADEA & $-0.142^{\mathrm{ns}}$ & $-0.154^{\mathrm{ns}}$ & $-0.185^{*}$ & $-0.017^{\mathrm{ns}}$ & $-0.046^{\mathrm{ns}}$ & $0.062^{\mathrm{ns}}$ & $0.013^{\mathrm{ns}}$ & $-0.051^{\mathrm{ns}}$ & $-0.053^{\mathrm{ns}}$ & $-0.049^{\mathrm{ns}}$ & $-0.087^{\mathrm{ns}}$ \\
\hline
\end{tabular}

ns, ${ }^{*}$ and ${ }^{* *}=$ non-significant at 5 e $1 \%$ of probability, respectively by the $t$ test.

Tests conducted: Water content (WC); Cold test (CT); water content of the electrical conductivity (WCEC); electrical conductivity (EC); germination at low temperature (GLT); length of shoot at low temperature (LSLT); length of root at low temperature (LRLT); dry weight of root at low temperature (DWRLT); dry weight of shoot at low temperature (DWSLT); accelerate aging (AG), water content before the accelerate aging (WCBAG) and water content after the accelerate aging (WCBAG).

Ciência Rural, v.47, n.3, 2017. 


\section{CONCLUSION}

The accelerated aging, electrical conductivity and field emergence of seedlings tests are the most efficient for classification of lots of corn seeds cv. 'Sertanejo' in levels of vigor, been the seeds of lot 1 the most vigorous.

\section{REFERENCES}

ARAÚJO, R. F. et al. Electrical conductivity test for mung beans seeds. Revista Brasileira de Sementes, v.33, n.1, p.123-130, 2011. Available from: $<$ http://www.scielo.br/scielo.php?script=sci_artte xt\&pid=S0101-31222011000100014>. Accessed: Nov. 25, 2012. doi: $10.1590 / \mathrm{S} 0101-31222011000100014$.

ASSOCIATION OF OFFICIAL SEED ANALYSTS (AOSA). Seed vigour testing handbook. East Lasing, 1983. 88p. (AOSA. Contribution, 32).

BARROS, A. S. R. et al. Cold test. In: KRZYZANOWSKI, F. C. et al. (Eds.). Vigor de sementes: conceitos e testes. Londrina: ABRATES, 1999. p.5.1-5.13.

BATISTA, N. A. S. et al. Evaluation of cowpea seed quality by electrical conductivity. Revista Ceres, v.59, n.4, p.550-554, 2012. Available from: $<$ http://www.redalyc.org/pdf/3052/305226898017. pdf $>$. Accessed: Mar. 25, 2012. ISSN 0034-737X.

BITTENCOURT, S. R. M. et al. Alternative methodology for the accelerated aging test for corn seeds. Ciência Rural, v.42, n.8, p.1360-1365, 2012. Available from: $<$ http://www.scielo.br/scielo.php?script=sci_arttext\&pid $=$ S0103-84782012000800005>. Accessed: June 02, 2012. doi: $10.1590 / \mathrm{S} 0103-84782012000800005$.

BRASIL. Ministério da Agricultura, Pecuária e Abastecimento. Rules for seed analysis. Ministério da Agricultura, Pecuária e Abastecimento. Secretaria de Defesa Agropecuária. Brasília: MAPA/ACS, 2009. 395p.

CARVALHO, N. M.; NAKAGAWA, J. Seeds: Science, technology and production. Jaboticabal: FUNEP, 2012. 590p.

COIMBRA, R. A. et al. Vigor tests for selection of sweet corn (sh2) seeds lot. Ciência Rural, v.39, n.9, p.2402-2408, 2009. Available from: <http://www.scielo.br/scielo.php?script=sci_arttext\&pid $=$ S0103-84782009000900004>. Accessed: May 09, 2012. doi: 10.1590/S0103-84782009000900004.

DIAS, D. C. F. S.; MARCOS FILHO, J. Vigor test based on the permeability of cell membranes: II Potassium leaching. Informativo ABRATES, v.5, n.1, p.37-41, 1995.

DIAS, D. C. F. S.; ALVARENGA, E. M. Germination test at low temperature. In: KRZYZANOWSKI, F. C. et al. (Eds.). Vigor de sementes: conceitos e testes. Londrina: ABRATES, 1999. p.7.1-7.4.

EMBRAPA MILHO E SORGO. Introduction and economical importance of corn. Available from: $<\mathrm{http}: / / \mathrm{www}$. sistemasdeproducao.cnptia.embrapa.br/FontesHTML/Milho/ Cultivodomilho/importancia.htm>. Accessed: Sept. 05, 2012.
FREITAS, R. A.; NASCIMENTO, W. M. Accelerated aging test on lentil seeds. Revista Brasileira de Sementes, v.28, n.3, p.59-63, 2006. Available from: <http://www.scielo.br/scielo. php?pid $=$ S0101-31222006000300009\&script $=$ sci_arttext $>$. Accessed:Feb. 02,2012. doi: 10.1590/S0101-31222006000300009.

GRABE, D. F. Measurement of seed vigor. Journal of Seed Technology, v.1, n.2, p.18-31, 1976.

GUISCEM, J. M. et al. Cold test and accelerated aging in the evaluation of vigor bean seeds. Revista de Ciências Agrárias, v.33, n.2, p.182-191, 2010. Available from: <http://www.scielo. gpeari.mctes.pt/scielo.php?pid=S0871-18X2010000200016\& script $=$ sci arttext $>$. Accessed: Feb. 02, 2012.

INTERNACIONAL SEED TESTING ASSOCIATION (ISTA). Handbook of vigour test methods. Zurich, Switzerland, 1981. 72p.

LUDWIG, M. P. et al. Bean plant performance originated from seeds with different physiological quality. Revista da FZVA, v.15, n.2, p.44-52, 2008. Available from: <http:// revistaseletronicas.pucrs.br/ojs/index.php/fzva/article/ view/3570>. Accessed: Jan. 20, 2012.

MARCOS FILHO, J. Accelerated aging test. In: KRZYZANOWSKI, F. C. et al. (Eds.). Vigor de sementes: conceitos e testes. Londrina: ABRATES, 1999. p.3.1-3.24.

MARCOS FILHO, J. Fisiologia de sementes de plantas cultivadas. Piracicaba: FEALQ, 2005. 425p.

MENDONCA, E. A. F. et al. Vigor tests in upland cotton seeds. Revista Brasileira de Sementes, v.30, n.3, p.1-9, 2008. Available from: $<$ http://www.scielo.br/scielo.php?script=sci ar ttext\&pid=S0101-31222008000300001>. Accessed: July 05, 2012. doi: 10.1590/S0101-31222008000300001.

MENEZES, N. L. et al. Drying temperatures on physical integrity, physiological quality and chemical composition of rice seeds. Pesquisa Agropecuária Tropical, v.42, n.4, p.430-436, 2012. Available from: <http://www.revistas.ufg.br/index.php/pat/article/ view/18457>. Accessed: Feb. 22, 2012. ISSN 1983-4063.

OHLSON, O. C. et al. Accelerated ageing test for seed wheat evaluation. Revista Brasileira de Sementes, v.32, n.4, p.118-124, 2010. Available from: $<$ http://www.scielo.br/scielo.php?script=sci arttext\&pid=S0101-31222010000400013 $>$. Accessed: Feb. 22, 2012. doi: 10.1590/S0101-31222010000400013.

OLIVEIRA, A. C. S. et al. Vigor tests in seeds based on plant development. América do Norte: Inter Science Place, 2009. N.4. Available from: <http://www.interscienceplace.org/isp/index.php/ isp/article/view/35>. Accessed: Jan. 20, 2012. ISSN: 1679-9844.

PICARELLI, G. A. Logistics characterization of the corn of main producing regions of Rio Grande do Sul State. 2012. Universidade de São Paulo "Escola Superior de Agricultura Luiz de Queiroz". Piracicaba, SP. Available from: <http://esalqlog. esalq.usp.br/wp-content/uploads/2015/05/Caracterizacaoda-logistica-do-milho-das-principais-regioes-produtorasdo-Estado-do-Rio-Grande-do-Sul-PICARELLI-G.-A..pdf> . Accessed: Nov. 11, 2012.

RIBEIRO, D. M. et al. Electrical conductivity test for vigor evaluation of popcorn seeds (Zea mays L.). Revista Ceres, 
v.56, n.6, p.772-776, 2009. Available from: <http://www.ceres. ufv.br/ojs/index.php/ceres/article/view/3503/1393>. Accessed: Feb. 10, 2012.

SOARES, M. M. et al. Vigor tests in sorghum seeds with emphasis to electrical conductivity. Revista Ciência e Agrotecnologia, v.34, n.2, p.391-397, 2010. Available from: <http://www.scielo.br/ scielo.php?pid $=$ S1413-70542010000200017\&script $=$ sci_arttext $>$. Accessed: Feb. 05, 2012. doi: 10.1590/S1413-70542010000200017.

TUNES, L. M. et al. Accelerated aging as test of vigor for rice seeds. Revista de Ciências Agrárias, v.35, n.1, p.120-127, 2012. Available from: $<$ http://www.scielo.gpeari.mctes.pt/scielo.php?pid $=\mathrm{S} 0871018 \mathrm{X} 2012000100011 \&$ script $=$ sci_arttext $>$. Accessed: Feb. 05, 2012. ISSN: 0871-018X.

VENANCIO, L. P. et al. Aging test for evaluation of the maize seed physiology quality. Revista Enciclopédia Biosfera, v.8, n.14, p.899-906, 2012. Available from: <http://www.conhecer.org.br/ enciclop/2012a/agrarias/teste\%20do.pdf>. Accessed: Jan. 12, 2012.

VIEIRA, R. D.; KRZYZANOWSKI, F. C. Electrical conductivity tests. In: KRZYZANOWSKI, F. C. et al. (Eds.). Vigor de sementes: conceitos e testes. Londrina: ABRATES, 1999. p.4.1-4.26.

VIEIRA, R. D. et al. Electrical conductivity and initial water content of soybean seeds. Pesquisa Agropecuária Brasileira, v.37, n.9, p.1333-1338, 2002. Available from: <http://www.scielo. br/pdf/pab/v37n9/13209.pdf>. Accessed: Feb. 05, 2012.

ZUCARELI, C. et al. Rates and time of nitrogen broadcasting on the physiological quality of sweet corn seed. Revista Brasileira de Sementes, v.34, n.3, p.480-487, 2012. Available from: $\quad<$ http://www.scielo.br/scielo.php?script=sci_arttext\&pid $=$ S0101-31222012000300016 $>$. Accessed: Jan. 12, 2012. doi: $10.1590 / \mathrm{S} 0101-31222012000300016$ 